\title{
Impacts of climate change on regional hydrological regimes of the Wujiang River watershed in the Karst area, Southwest China
}

\author{
Nianxiu Qin ${ }^{1,3,4}$, Junneng Wang ${ }^{1,4^{*}}, X_{i}$ Chen $^{2}$, Guishan Yang ${ }^{3}$ and Haoyuan Liang ${ }^{1,4}$
}

\begin{abstract}
Background: The impacts of climate change on streamflow in the Wujiang River watershed of Guizhou Province, Southwest China, were investigated by using a monthly distributed hydrological model and the two-parameter climate elasticity of streamflow approach.

Results: Results showed two different approaches obtained almost identical results in term of precipitation elasticity of streamflow, which is about 1.42 across different emission scenarios. Precipitation is the primary factor controlling runoff generation. However, the effects of temperature on the streamflow cannot be neglected with evidences of opposite signs of future precipitation and streamflow; the slight decline of streamflow is associated with an increase of precipitation and a higher temperature.

Conclusion: While the magnitudes of annual mean streamflow responses are minor, there would be a seasonal shift: drier spring and wetter summer would potentially result in the increasing frequency of spring drought events and summer flooding, and would produce serious challenge for water resources planning and management for Southwest China.
\end{abstract}

Keywords: Climate change; Climate elasticity of streamflow; Karst area; Monthly distributed hydrological model; Southwest China

\section{Background}

Guizhou Province, with an area of over 176,000 square kilometres (about 67,958 square miles) with a total population of more than $35,245,000$ is located in the southwest China. It adjoins Sichuan Province to the north, Yunnan Province to the west, Guangxi Zhuang autonomous region to the south and Hunan Province to the east. Southwest China is one of the most abundant water resources in China with many large rivers, such as the Yangtze River (the 3rd longest river in the world after the Nile and Amazon, and the longest and largest river in China), the Pearl River, the Mekong River (the longest-river in Southeast Asia), the Salween River, and the Ganges. However, there is a serious shortage of

\footnotetext{
*Correspondence: wjunneng@163.com

${ }^{1}$ Laboratory of Beibu Gulf Environment Change and Resources Use, Ministry of Education, Guangxi Teachers Education University, Nanning 530001, China ${ }^{4}$ The Collaborative Innovation Center of the Ecological Environment \& Integration Development in the Xijiang River Basin, Xijiang River, China Full list of author information is available at the end of the article
}

drinking water for people and livestock, and more than $50 \%$ cities and towns in the karst regions of Guizhou Province face a shortage of water (Huang, 2007). The main reasons include, but are not limited to the uneven distribution of water resources in space and time, the most complex topography in the world, relatively poor vegetation cover, and the thinning of soil layers and outcropping of bedrocks (Ford and Williams 1989).

The Guizhou Province is characterized by an extremely fragile environment resulting from serious ecosystem destruction, termed "karst rocky desertification" (Song et al., 1983; Yang, 1988; Wang et al., 2004a, b; Yang et al., 2009). The rock desertification intensifies loss of water and soil in karst mountain areas, so the environmental hazards become frequent and the quality of land worsen. Karst environment problems in China have been paid specific attentions by the governments because of broad expansion of karst area, dense population, and rich natural resources in this region (Yuan, 1997). 
The two-layer structure (surface and subsurface) in karst areas are unique, as a result, the hydrologic systems are characterized by the existence of underground drainage networks which are uneven in distribution and linear, feathered or dendritic in shape. They tend to be closely related with surface water and precipitation and to have rather great amplitude of fluctuation in water regime (Yuan, 1997; Butscher and Huggenberge, 2009). The impacts of precipitation and temperature changes on regional hydrological and ecological environment and rocky desertification have been identified (Guo et al., 2002; China's National Climate Change Program, 2007), especially under the change of extreme climate scenarios, such as the severe drought crippling southwest China between autumn 2009 and May 2010 (Hance, 2010). This is because global warming could alter hydrologic processes and cycles, as well as water availability and its distribution, water quality, water demand and usage (Wurbs et al., 2005; Fu et al., 2007a).

Numerous studies have documented the sensitivity of streamflow to climatic changes for watersheds all over the world (Gleick, 1990; Lettenmaier, 1991; Smith and Richman 1993; Yates and Strzepek 1998; Sankarasubramanian et al. 2001; McCarthy et al. 2001; Arnell 2002; Fu et al. 2004). The sensitivity of streamflow of Major river basin in China to climatic changes has been investigated, for example Yellow river basin, Yangtze River basin, Haihe River, Luanhe river, Zhujiang River basin and so on, especially in the Yellow River Basin and the Yangtze River basin (Zhang et al. 2000; Fan et al., 2003; Yuan et al., 2005; Wang 2006; Hao et al., 2006; Zhang and Wang, 2007; Fu et al., 2007b; Jin et al., 2009; Chen et al., 2012). Fu et al., (2007b) examines the impacts of climate variability upon the regional hydrological regimes of the Yellow River in China, results indicate that the average annual precipitation is $494.8 \mathrm{~mm}$ in La Niña years and only $408.8 \mathrm{~mm}$ in El Niño years, The relationship among the stream-flow, precipitation, and temperature indicates stream-flow is sensitive to both precipitation and temperature, For small precipitation increases (less than $13 \%)$, the stream-flow percentage change is less than the precipitation change for the Yellow River. Jin et al. (2009) analyzed the impact of future climate change on water resources in Yangtze River basin with a way of developing and applying a large-scale statistical and concept hydrological model and collecting output data of air temperature and precipitation under different discharge situation of 24 modes of global climate. The results show that the runoff amount will decrease slightly in the future 20 30 years, and after that the value will obviously increase. Based on the means of Variable Infiltration Capacity (VIC) Model combining with Providing Regional Climate for Impact Studies (PRECIS) Model, hydrological variation in Haihe river basin due to climate change has been investigated by Yuan et al. (2009), the results show that in spite of the increase of rainfall the mean annual runoffs for different future climate scenarios are tend to decrease which implies more serious water shortage will occur. If the population increase in 21 st century is taken into consideration the shortage of water resources will be more rigorous. Moreover, an increase of runoff in flood season for future climate scenarios is found, indicating a larger possibility of flooding will happen to the basin in the future. The above analysis shows that different scholars from different angles with different ways analyzed the impact of climate change on hydrology and water resources in these areas. The analysis results show that different level influence has been caused by climate change in different watershed.

Wujiang River is the largest tributary in the upstream of the Yangtze River basin, mainly flowing in a Karst environment in Guizhou Province, southwest China. The majority of existing studies in the literature for the Wujiang River watershed were focused on chemical composition, characteristics of nutrients of river water and affecting factors of overland flow, etc. For example, Han and Liu (2001) investigated the hydrogeochemistry of the Wujiang River in Guizhou Province. Jiang et al. (2005) analysis the Damming effects on the distribution of mercury in the Wujiang River. Zhu et al. (2005) studied the distribution characteristics of nutrients in the Wujiang River watershed. Recently, there were studies about the effect of rainfall-runoff process and the relationship between surface runoff and precipitation based on different land use and land cover in the Wujiang River Catchment (Fu et al., 2008), which reported that land cover, land use and soil surface coverage have a great impact on the occurrence and amount of overland flow within the same rainfall process, overland flow occurs first on farmland, then on grassland, and finally on forestland. Tang and Liu (2007) examined the relationship between surface runoff, precipitation and present land use based on GIS method to simulate surface runoff in the Wujiang River watershed.

This primary objective of this study is to investigate the hydrological processes as a result of climate change for the Wujiang River watershed, which has not been reported in the literature, by using a distributed monthly hydrological model, the two-parameter climate elasticity of streamflow index resulting from observational historical data, and the Intergovernmental Panel on Climate Change (IPCC) Fourth Assessment Report (AR4) GCMs model outputs. The aim of this study is to provide a reference for regional water resource planning and management and restoration and reconstruction of Karst eco-environment area, and possibly a basis for better understanding the hydrological processes and sustainable development of Karst area under climate change scenarios. 


\section{Methods}

\section{Catchment description}

The Wujiang River (Figure 1) is the largest tributary on the southern bank of the upper reaches of the Yangtze River. The mountainous river originates in the Wumeng ranges on the Yunnan-Guizhou Plateau and winds its way through four provinces including Yunnan, Guizhou, Chongqing and Hubei, with a total length of $1,037 \mathrm{~km}$. It flows across the west, central, northeastern of Guizhou Province. The elevation of the watershed is $\sim 1500 \mathrm{~m}$ in its upper reaches and $\sim 500 \mathrm{~m}$ in its lower reaches (Han and Jin, 1996). The drainage basin of the Wujiang River $\left(26^{\circ} 10^{\prime}-29^{\circ} 45^{\prime} \mathrm{N}, 104^{\circ} 05^{\prime}-108^{\circ} 30^{\prime} \mathrm{E}\right)$ covers an area of $87,920 \mathrm{~km}^{2}$, with an annual streamflow of $5.34 \times 1010 \mathrm{~m}^{3}$, and a runoff coefficient of 0.531 (Han and Liu, 2001). The rainy season usually starts in April, reaches the wettest in June, and ends in October. The streamflow fluctuates closely in accordance with precipitation. The inter-annual variation of temperature is similar to these of precipitation and streamflow, having its maximum value in July (Figure 2). The prevailing subtropical monsoon climate brings $880-1300 \mathrm{~mm}$ of annual rainfall (1956-2008) to the watershed, which decreases from south to north and from west to east. The annual mean streamflow ranges from 337 to $896 \mathrm{~m}^{3} / \mathrm{s}$ (1956-2000) and increases from west to east.

The Guizhou Province has about 11 water resources units, and the Wujiang River watershed is the largest among them with a complete water system (Figure 1). It is one of the main agricultural producing areas, as well as an important industrial zone in Guizhou Province. Therefore, it has been chosen in this study to investigate the impacts of climate change on hydrological regimes.

\section{Datasets}

Thirty-five meteorological stations in Guizhou Province, having consecutive daily data during 1960-2008 of precipitation, mean, maximum and minimum temperatures, humidity, and wind speed, were used in this study. These stations, all within the Wujiang River watershed (Figure 1), are maintained according to standard methods by the National Meteorological Administration of China, which applies data quality control before releasing these data. The climate variables, except precipitation, were used to calculate potential evaporation $\left(E T_{\mathrm{p}}\right)$ by using the Priestley-Taylor model (Qin et al., 2010a).

Continuous monthly streamflow data in Yachihe, Wujiangdu, Jiangjiehe and Sinan stations (Table 1) from

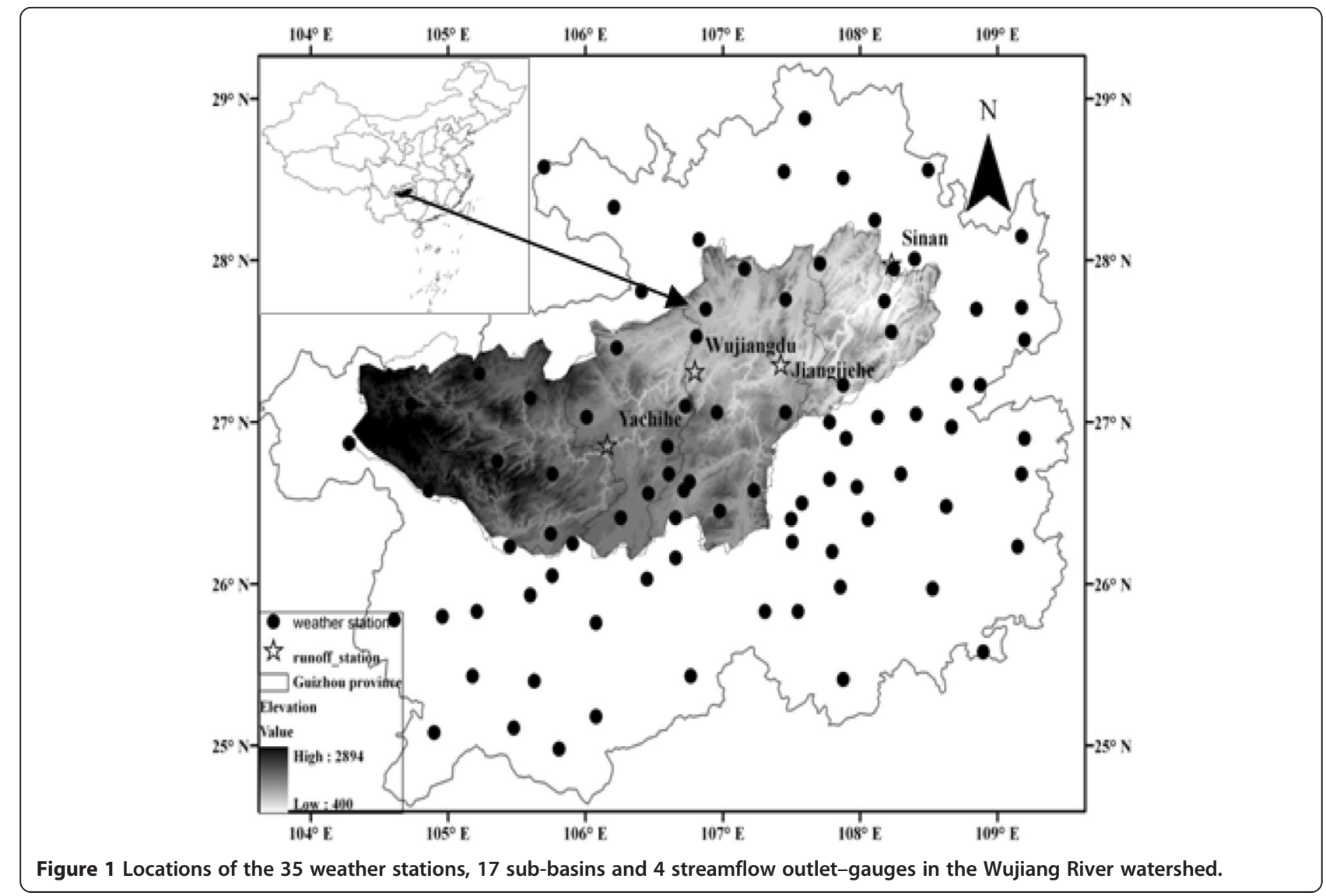




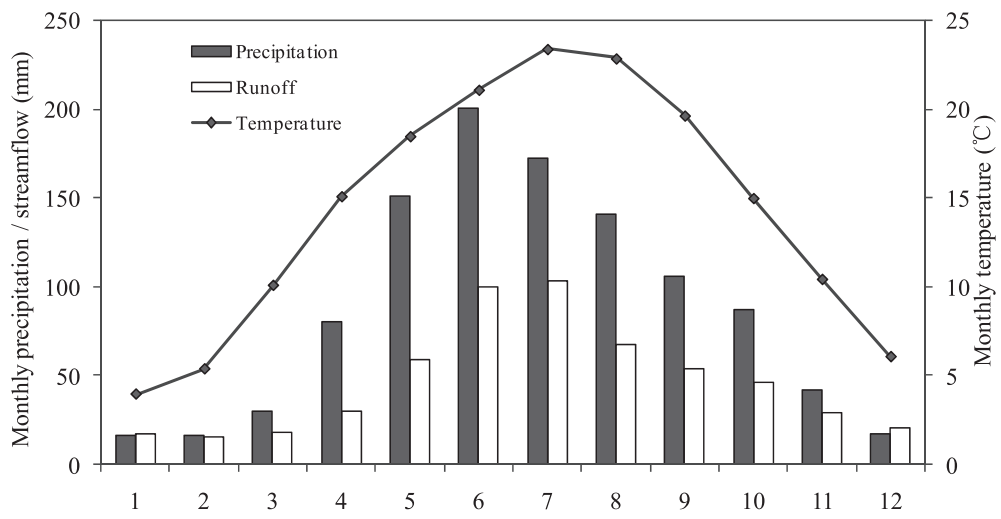

Figure 2 Monthly precipitation, runoff and temperature of the Wujiang River watershed.

1971 to 2000 were used in this study to calibrate and validate the monthly hydrological model: it was calibrated against streamflow data from 1971 to 1990 and validated for 1991-2000 with the potential $E T\left(E T_{\mathrm{p}}\right)$ calculated from the Priestley-Taylor formula instead of pan evaporation data.

DEM data of $90 \times 90 \mathrm{~m}$ grid resolution were used to describe the spatial variations of topography and to divide sub-basins in the Wujiang River watershed. The 17 sub-basins were created based on gauges locations and the DEM (Figure 1).

There are 24 GCMs (A1B scenarios), 21 GCMs (B1 scenarios) and 19 GCMs (A2 scenarios) being available at the time of study at the IPCC Data Distribution Centre website (http://ipcc-ddc.cru.uea.ac.uk) (Table 2). Since GCM horizontal resolution varies, the GCMs outputs were interpolated to a uniform resolution of $2.5^{\circ} \times 2.5^{\circ}$. This leads to 12 grid cells over the Wujiang River catchment. The study period is from 1961 to 2100 , while 1961-2000 as base period and 2000-2100 for future climate change scenarios.

\section{Methodology}

\section{The distributed monthly hydrological model}

The hydrological simulations were performed with a distributed monthly hydrological model which was developed by adopting and combining the techniques of the Xin'anjiang model and TOPMODEL (Chen et al., 2007). Based on the variable source area concept, we considered basin topography and rainfall to be two major factors whose spatial variations play a dominant role in runoff generation and developed a monthly model that is able to account for influences in the spatial and temporal dynamics of water balance (Chen et al., 2007). Specifically, the model is composed of four major components (Xue, 2010) (Figure 3):

1) The first component is the calculation of actual evapotranspiration $E T_{a}$ based on available soil moisture content $W_{t}$ and potential evapotranspiraion $E T_{p}$; in general, accurate estimates of evaporation are required to reduce uncertainties in constructing weekly to monthly water balances at catchment and regional scales (Xiong and Guo 1999). Usually, Pan evaporation multiplying a conversion coefficient $(\eta)$ is used to calculate $E T_{p}$ in the distributed monthly hydrological model. For driving the model with meteorological data as input, $E T_{p}$ can be estimated by using meteorological data. After comparing of models for estimating potential evapotranspiration in Guizhou Province, SW China, the radiation-based evapotranspiration models were selected (Qin et al., 2010a), so Priestley-Taylor model were chosen for potential evapotranspiration in this study. Priestley-Taylor (1972):

$E T=\alpha \frac{\Delta}{\Delta+\gamma} \frac{R_{n}}{\lambda}$

where, ET is the Potential evapotranspiration, $R_{\mathrm{n}}$ is the net radiation of surface $\left(\mathrm{cal} /\left(\mathrm{cm}^{2} . \mathrm{d}\right)\right), \Delta$ is the

Table 1 Four hydrological sub-basin outlet-gauges of the Wujiang River watershed (1971-2000)

\begin{tabular}{|c|c|c|c|c|c|c|}
\hline Station & Abbreviation & $\begin{array}{l}\text { Drainage } \\
\text { Area }\left(\mathrm{km}^{2}\right)\end{array}$ & $\begin{array}{l}\text { Precipitation } \\
(\mathrm{mm} / \mathrm{a})\end{array}$ & $\begin{array}{l}\text { Streamflow } \\
\text { depths (mm/a) }\end{array}$ & $\begin{array}{l}\text { Runoff } \\
\text { coefficient }\end{array}$ & $\begin{array}{l}\text { Actual } \\
\text { evaporation }(\mathrm{mm} / \mathrm{a})\end{array}$ \\
\hline Yachihe & YCH & 16,541 & 1042.9 & 645.6 & 0.62 & 397.3 \\
\hline Wujiangdu & WJD & 26,496 & 1060.0 & 580.5 & 0.55 & 479.4 \\
\hline Jiangjiehe & JJH & 43,292 & 1059.7 & 522.3 & 0.49 & 537.3 \\
\hline Sinan & SN & 50,791 & 1076.0 & 558.8 & 0.52 & 517.2 \\
\hline
\end{tabular}


Table 2 Global climate models (GCMs) used in this study

\begin{tabular}{|c|c|c|c|c|c|}
\hline \multirow{3}{*}{ Models } & \multicolumn{3}{|l|}{ ID } & \multirow{3}{*}{ Country } & \multirow{3}{*}{ Source } \\
\hline & A1 & B & A & & \\
\hline & B & 1 & 2 & & \\
\hline BCCR.BCM20 & 1 & 1 & 1 & Norway & $\begin{array}{l}\text { Bjerknes Centre for Climate Research, } \\
\text { University of Bergen, Norway }\end{array}$ \\
\hline CCMA.CGCM3.1_T47 & 2 & 2 & 2 & Canada & $\begin{array}{l}\text { Canadian Centre for Climate Modeling } \\
\text { and Analysis }\end{array}$ \\
\hline CCMA.CGCM3.1_T63 & 3 & 3 & & Canada & $\begin{array}{l}\text { Canadian Centre for Climate Modeling } \\
\text { and Analysis }\end{array}$ \\
\hline CCMA.CGCM3.1_T & 4 & 4 & 3 & France & $\begin{array}{l}\text { Meteo-France/Centre National de } \\
\text { Research Meteorologiques }\end{array}$ \\
\hline CSIRO.MK30 & 5 & 5 & 4 & Australia & $\begin{array}{l}\text { Australian Commonwealth Scientific } \\
\text { Industrial and Research Organisation }\end{array}$ \\
\hline CSIRO.MK35 & 6 & 6 & 5 & Australia & $\begin{array}{l}\text { Australian Commonwealth Scientific } \\
\text { Industrial and Research Organisation }\end{array}$ \\
\hline GFDL.CM20 & 7 & 7 & 6 & USA & Geophysical Fluid Dynamics Laboratory \\
\hline GFDL.CM21 & 8 & 8 & 7 & USA & Geophysical Fluid Dynamics Laboratory \\
\hline GISS.AOM & 9 & 9 & & USA & NASA Goddard Institute of Space Studies \\
\hline GISS.EH & 10 & & & USA & NASA Goddard Institute of Space Studies \\
\hline GISS.ER & 11 & 10 & 8 & USA & NASA Goddard Institute of Space Studies \\
\hline IAP.FGOALS_g10 & 12 & 11 & & China & $\begin{array}{l}\text { Institute of Atmospheric Physics, Chinese } \\
\text { Academy of Sciences }\end{array}$ \\
\hline INGV.ECHAM4 & 13 & & 9 & Italy & $\begin{array}{l}\text { National Institute of geophysics and } \\
\text { volcanology Italy }\end{array}$ \\
\hline INM.CM30 & 14 & 12 & 10 & Russia & Institute for Numerical Mathematics \\
\hline IPSL.CM4 & 15 & 13 & 11 & France & Insitut Pierre-Simon Laplace \\
\hline MIROC3.2_hires & 16 & 14 & & Japan & $\begin{array}{l}\text { National Institute for Environmental } \\
\text { Studies Japan }\end{array}$ \\
\hline MIROC3.2_medres & 17 & 15 & 12 & Japan & $\begin{array}{l}\text { National Institute for Environmental } \\
\text { Studies Japan }\end{array}$ \\
\hline MIUB.ECHO_G & 18 & 16 & 13 & Germany & $\begin{array}{l}\text { Meteorological Institute of the } \\
\text { University of Bonn }\end{array}$ \\
\hline MIUB.ECHAM5 & 19 & 17 & 14 & Germany & Max-Planck-Institut fur Meteorologie \\
\hline MRI.CGCM2.3.2 & 20 & 18 & 15 & Japan & Meteorological Research Institute \\
\hline NCAR.CCSM3 & 20 & 19 & 16 & USA & $\begin{array}{l}\text { National Center for Atmospheric } \\
\text { Research }\end{array}$ \\
\hline NCAR.PCM & 22 & 20 & 17 & USA & $\begin{array}{l}\text { National Center for Atmospheric } \\
\text { Research }\end{array}$ \\
\hline UKMO.HadCM3 & 23 & 21 & 18 & UK & UK Met. Office,UK \\
\hline UKMO.HadGEM1 & 24 & & 19 & UK & UK Met. Office,UK \\
\hline
\end{tabular}

saturation vapor pressure-temperature curve slope, $\gamma$ is the Psychrometer constant $\left(\operatorname{mbar} /{ }^{\circ} \mathrm{C}\right), \lambda$ is the latent heat of evaporation( $\mathrm{cal} / \mathrm{g}), \alpha$ : suggested value 1.26 .

2) The second component uses the concept of the TOPMODEL to estimate the spatial distribution of soil moisture deficit from terrain characteristics and simulates runoff $(R)$ based on the runoff generation theory adopted in the Xin'anjiang model, i.e. runoff generation after filling up the field capacity of soils.
3) The third component estimates the baseflow recession theory to divide runoff components, such as surface and subsurface runoff in the original model. For karst watersheds, runoff components are divided as fast flooding runoff from surface of hillslope and epikarst zone $R_{\text {Fast }}$, underground flow from large fractures and conduits $R_{\text {Mid }}$ and underground flow from small fractures $R_{\text {Slow }}$ based on characteristics of flow discharge recession analysis (Xue, 2010).

4) In the fourth component, streamflow from a sub-basin outlet is routed by a simple linear reservoir storage 


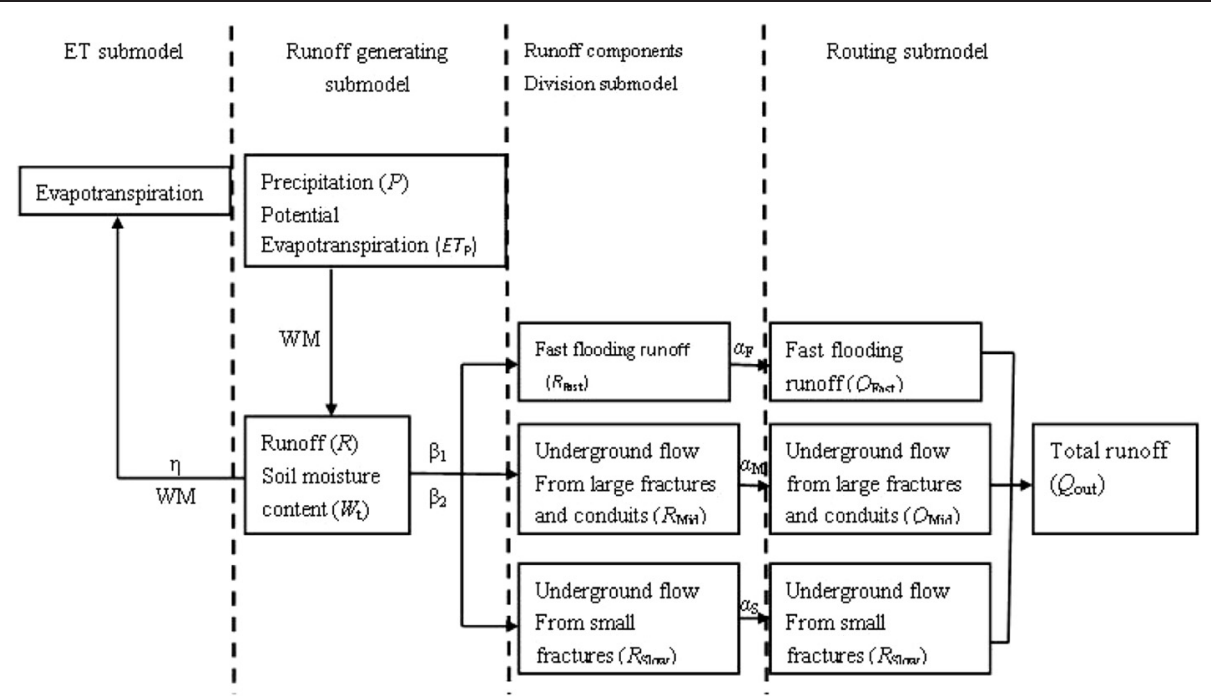

Figure 3 Model components of the Karst distributed monthly hydrological model variable and parameters. Where $\eta$ is the Pan evaporation conversion coefficient; $1-\beta 1$ is the proportion of fast flooding runoff in total runoff; $\beta 1 \times \beta 2$ is the proportion of the underground flow from small fractures in total runoff; WM is the average storage capacity; $a \mathrm{~F}$ is the Fast flooding runoff; $a \mathrm{M}$ is the underground flow from large fractures and conduits; aS is the underground flow from small fractures) (Xue, 2010).

routing technique (Chen et al., 2007). The detailed description of model was given by Chen et al. (2007) and Xue (2010).

\section{Criteria for model Calibration and Validation}

Two criteria were used in this study to assess the distributed monthly hydrological models performance: the Nash-Sutcliffe Efficiency (NSE) (Nash and Sutcliffe, 1970) and the root mean square error (RMSE), defined as:

$$
\begin{aligned}
& N S E=1-\frac{\sum_{i=1}^{n}\left(Q_{o b s, i}-Q_{s i m, i}\right)^{2}}{\sum_{i=1}^{n}\left(Q_{o b s, i}-\bar{Q}_{o b s}\right)^{2}} \\
& \text { RMSE }=\sqrt{\frac{\sum_{i=1}^{n}\left(Q_{o b s, i}-Q_{s i m, i}\right)^{2}}{n}}
\end{aligned}
$$

where $Q_{\text {sim }}$ and $Q_{o b s}$ are the simulated and observed monthly streamflow, respectively, $\bar{Q}_{o b s}$ is the arithmetic monthly mean of the observed streamflow, $i$ is the $i$ th month and $n$ is the total number of month used for simulation.

The two-parameter climate elasticity of streamflow

In the study, the streamflow-precipitation-temperature relationship and the two-parameter climate elasticity of streamflow approach developed by $\mathrm{Fu}$ et al., (2007a, 2007b) were used. Firstly, based on the methodology of Risbey and Entekhabi (1996), we can calculate the annual anomalies of streamflow, precipitation and temperature from their long-term means of one calendar year's observed data and plot in a precipitation-temperature plane.
Each point in the plane thus represents the departure from the long term mean of one calendar year's observed data. Secondly, ArcGIS Geostastical Analyst produces the contours of streamflow percentage change. Thirdly, the streamflow-precipitation-temperature relationship is converted into a climate elasticity of streamflow index:

$$
e_{P, \& T}=\left(\frac{Q_{P, \& T}-\bar{Q} \bar{P}}{P_{P, \& T}-\bar{P} \bar{Q}}\right)
$$

where $\delta \mathrm{T}=(\mathrm{T}-\overline{\mathrm{T}})$ is the temperature departure, $\bar{P}$ and $\bar{Q}$ is the long-term average of precipitation and streamflow, respectively. $Q_{P . \delta T}$ is the runoff under only change the temperature; $P_{P . \delta T}$ is the precipitation under the temperature change.

This climate elasticity of streamflow index is a conditional precipitation elasticity of streamflow index accounting for the effects of temperature from the temperatureprecipitation plane, i.e., it is not an index of the full joint precipitation and temperature elasticity of streamflow. However, as a function of precipitation and temperature it can be used to assess the climatic effects of joint precipitation and temperature changes on hydrological regimes at basin scales. Thus for a given precipitation and temperature change scenario (if the scenario is in the range of past observed climate), this index can predict the annual streamflow response (Fu et al., 2004; 2007b).

\section{Results and discussion}

\section{Model calibration and validation}

The calibration and validation results of the 17 subbasins were shown in Table 3, and Figure 4 was graphic 
Table 3 Results of hydrological model calibration(1971-1990)and validation (1991-2000) of the Wujiang River watershed

\begin{tabular}{|c|c|c|c|c|c|c|c|c|c|}
\hline \multirow[t]{2}{*}{ Sub-basin } & \multirow[t]{2}{*}{ Basin Areas $\left(\mathrm{km}^{2}\right)$} & \multicolumn{4}{|c|}{ Calibration (1971-1990) } & \multicolumn{4}{|c|}{ Validation (1991-2000) } \\
\hline & & Sim & Obs & NSE & RMSE (mm) & Sim & Obs & NSE & RMSE (mm) \\
\hline Yachihe & 16,541 & 61.38 & 51.96 & 0.84 & 18.61 & 63.70 & 55.56 & 0.82 & 23.67 \\
\hline Wujiangdu & 26,496 & 47.67 & 47.25 & 0.82 & 15.91 & 50.49 & 51.33 & 51.330 .76 & 22.08 \\
\hline Jiangjiehe & 43,292 & 45.68 & 44.78 & 0.75 & 17.69 & 49.21 & 48.99 & 0.81 & 19.76 \\
\hline Sinan & 50,791 & 43.50 & 44.86 & 0.85 & 13.46 & 48.18 & 53.90 & 0.82 & 20.25 \\
\hline
\end{tabular}

results of the selected four sub-basins. The NSEs for the calibration and validation period varies from 0.71 to 0.88 and from 0.59 to 0.93 , respectively. During the validation period, the NSEs were less than 0.7 at four gauges: Xiangjiang (0.59), Liyutang (0.59), Yuqing (0.65) and Changheba (0.66), and larger than 0.7 for the rest of 13 gauges, five of which being larger than 0.9: Sanchahe, Wujiangdu, Jiangjiehe, Yachihe and Sinan gauges. The RMSE of all sub-basins during the calibration and validation period ranges between $9.49 \mathrm{~mm}$ and $15.38 \mathrm{~mm}$.

Figure 4 showed the simulated and observed streamflow during the calibration and validation period for the selected four sub-basins. It seems that the hydrograph shape is consistent with observed values. The model was calibrated well to the measured monthly streamflow depth for the four sub-basins, and the calibrated model performs satisfied for the validation data. As shown in Figure 4, hydrographs of the Wujiang River catchment have an obvious peak in June-September. Overall streamflow from November to next April (dry seasons) was slightly underestimated both in calibration and validation periods for all four sub-basins. Due to steeper topography and karst effect on baseflow, all the precipitation cannot turn into streamflow promptly in rainy seasons and part of them turn into streamflow in dry seasons, resulting in slightly higher streamflow in dry seasons than the observed data. Simulated streamflow could capture the observed peak flows in 1974, 1981 and 1972, while overestimates in 1975 and underestimates in 1976-1979. In general, the distributed monthly hydrological model has sufficient accuracy for monthly runoff for both calibration and validation periods (Figure 4), based on the performance criteria according to the standards for hydrological information and hydrological forecasting (Information center of the Ministry of Water Resources of China 2000), that is model efficiency coefficient is above 0.5 , and the root mean square error of below $25 \mathrm{~mm}$ can think model suitable for the area.

The calibrated hydrological model was re-run for 19612000 with the potential ET (ETp) calculated from the Priestley-Taylor formula in Yachihe, Wujiangdu, Jiangjiehe and Sinan stations (Table 1) to explore the sensitivity of using calculated ETp instead of pan evaporation data to drive the hydrological model. The simulation results were shown in Figure 5 and Table 4. In general, both simulated runoff volumes and hydrograph shape were consistent with observed values. The NSE of four sub-basins range from 0.76 to 0.84 , the RE is $0.76 \%-6.09 \%$ and the RMSE is between $5.85 \mathrm{~mm}$ and $6.91 \mathrm{~mm}$. These values satisfy the performance criteria set by the standard for hydrological information and hydrological forecasting of China (Information center of the Ministry of Water Resources of China 2000). It justifies that the calibrated distributed monthly hydrological model coupled with meteorological data could be used to investigate the effects of climate change on hydrological regimes in the study region with future meteorological data projected by IPCC AR4 models.

\section{Streamflow responses to future climatic change Simulation by using the distributed monthly hydrological model}

The change of future precipitation and temperature Since most GCMs do not simulate observed 20th century climate accurately at regional scales (Giorgi and Francisco 2000; Phillips and Gleckler 2006), we cannot compare the model projections directly with current observed data. Instead, we compare the projections with their respective 4AR 20th century runs $\left(20 c_{3} \mathrm{~m}, 1961-\right.$ 2000) (Fu et al., 2009). The differences in climate are treated as changes due to increasing emissions. In order to be consistent with the 20th century runs, climate projections for each future time period are averaged over 40 years of model output in this study. That 2030s is obtained from the period 2011-2050, that for 2050s from 2031-2070, and that for 2080s from 2061-2100. Three IPCC standard emission scenarios, A1B, A2 and B1, were used in this study.

\section{Temperature}

Figure 6a is the future temperature change for 2030s, 2050s and 2080s across three IPCC emission scenarios. Although there are differences between GCMs, all GCMs for the three periods exhibit a warming trend and the magnitudes of the increasing trend are consistent with the last 50 years observed data which can be analyzed by Qin et al. (2010b). The temperature increasing 

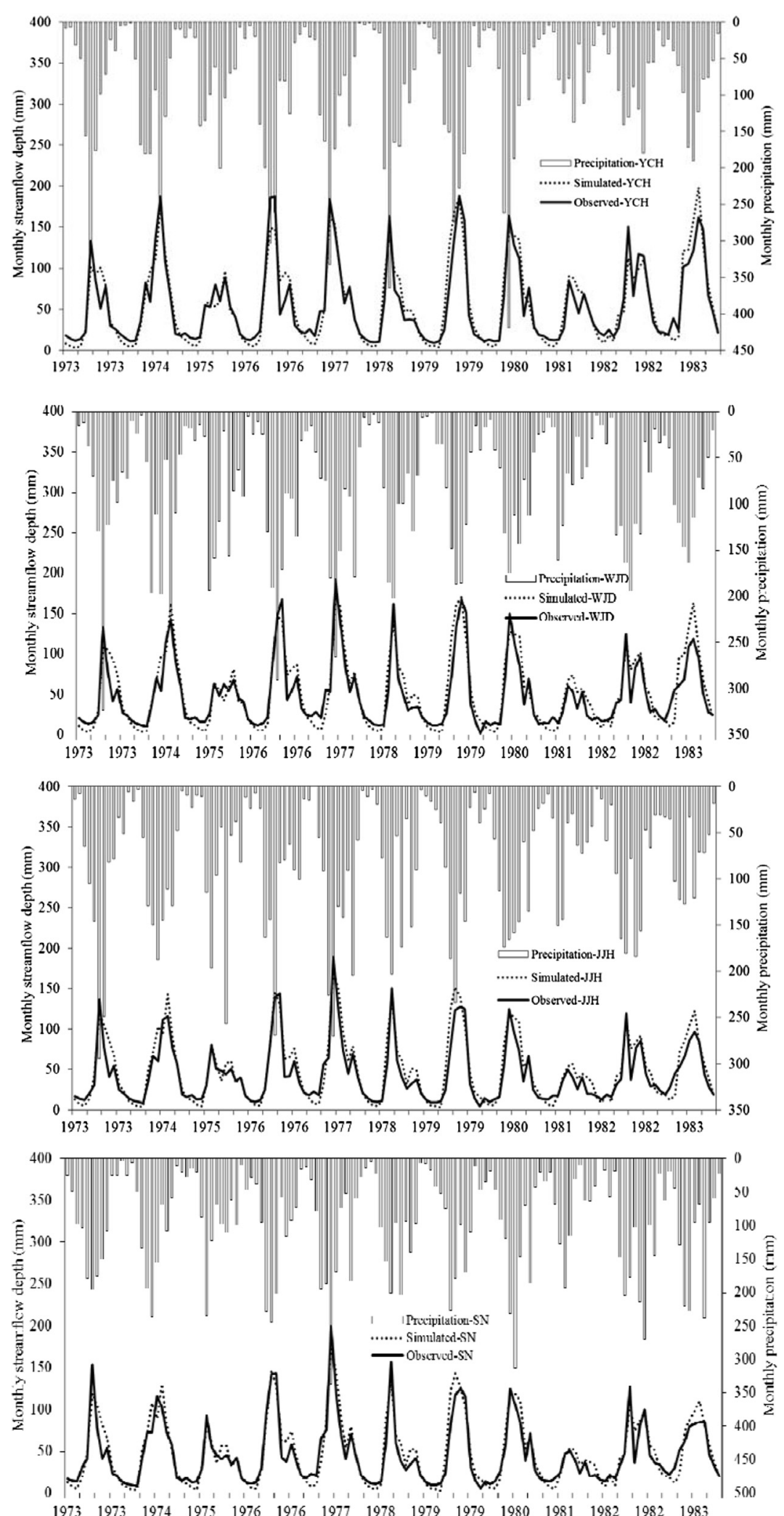

Figure 4 The simulated results of monthly streamflow in wujiang river Basin. 
Table 4 Results of model re-validation of the Wujiang River watershed at four sub-basin outlets (1961-2000)

\begin{tabular}{lllll}
\hline Gauges Name & Yachihe & Wujiangdu & Jiangjiehe & Sinan \\
\hline Basin Areas $\left(\mathrm{km}^{2}\right)$ & 16,541 & 26,496 & 43,292 & 50,791 \\
Simulation $(\mathrm{mm})$ & 627.1 & 596.8 & 566.0 & 563.5 \\
Observation $(\mathrm{mm})$ & 646.8 & 582.8 & 529.8 & 567.8 \\
NSE & 0.76 & 0.80 & 0.78 & 0.84 \\
RMSE $(\mathrm{mm})$ & 6.91 & 6.57 & 5.85 & 5.85 \\
\hline
\end{tabular}

magnitudes are $1.25^{\circ} \mathrm{C}\left(0.67-1.71^{\circ} \mathrm{C}\right), 2.01^{\circ} \mathrm{C}\left(1.26-2.74^{\circ} \mathrm{C}\right)$ and $2.98^{\circ} \mathrm{C}\left(2.11-4.3^{\circ} \mathrm{C}\right)$ under $\mathrm{A} 1 \mathrm{~B}$ scenarios, and $1.09^{\circ} \mathrm{C}$ $\left(0.38-1.62^{\circ} \mathrm{C}\right), 1.55^{\circ} \mathrm{C}\left(0.81-2.17^{\circ} \mathrm{C}\right)$ and $2.09^{\circ} \mathrm{C}(1.23-$ $\left.3.06^{\circ} \mathrm{C}\right)$ under $\mathrm{B} 1$ scenarios and $1.14^{\circ} \mathrm{C}\left(0.45-1.66^{\circ} \mathrm{C}\right)$, $1.85^{\circ} \mathrm{C}\left(1.14-2.56^{\circ} \mathrm{C}\right)$ and $3.25^{\circ} \mathrm{C}\left(2.46-4.51^{\circ} \mathrm{C}\right)$ under $\mathrm{A} 2$ scenarios, for the 2030s, 2050s and 2080s, respectively.

As shown in Figure 6a, the divergence between three emission pathways increases with time, e.g. the annual temperature difference between scenarios $\mathrm{A} 2$ and $\mathrm{B} 1$ is only $0.05^{\circ} \mathrm{C}$ for $2030 \mathrm{~s}$, but increases to $0.3^{\circ} \mathrm{C}$ by $2050 \mathrm{~s}$, even to $1.15^{\circ} \mathrm{C}$ by $2080 \mathrm{~s}$. The difference is also increasing with time, which is easily understandable.

\section{Precipitation}

The change of future precipitation is more complex as compared with temperature change, as shown in Figure 7a. The precipitation changes from 2030s, 2050s, to 2080s are $0.67 \%$ (-5.66 to $7.57 \%), 3.06 \%$ (-8.01 to $11.71 \%$ ) and $5.86 \%$ (-3.19 to $18.57 \%)$ respectively under A1B scenarios, $0.55 \%$ (-3.76 to $8.1 \%), 1.38 \%$ ( -5.36 to $10.47 \%$ ) and $3.2 \%$ $(-4.18$ to $16.91 \%)$ under B1 scenarios, and $-0.92 \%(-10.55$ to $8.19 \%$ ), $0.53 \%$ ( -8.37 to $11.56 \%$ ), $3.7 \%$ ( -7.12 to $16.76 \%$ ) under A2 scenarios. Although there are differences between GCMs, an overall slight increase of precipitation is prevalent (Figure 6a). The magnitude of precipitation trend and the numbers of GCM with a precipitation increasing increase gradually with time.

Comparisons of individual GCM showed disagreement on the signs of the future precipitation changes, e.g. the model of GISS-ER projected an increase of $7.57 \%$ while GFDL-CM21 a decrease of $5.66 \%$ for 2030 s. The difference is $13.23 \%$, indicating different GCM precipitation results are more uncertain and more challenging for decision-makers to use, but little divergence between three emission pathways.

\section{Impacts of temperature change on streamflow}

Although there is a slightly difference of streamflow responses resulting from different GCMs, the future streamflow would decrease with a temperature increasing scenario (Figure 6b). If the future precipitation keeps in consistent (in other words, the future precipitation keeps in consistent means the temperature data gained by from Figure 8 when the precipitation change is 0 ), the streamflow would change about $-4.62 \%,-5.33 \%$ and $-6.23 \%$ under A1B scenarios; $-4.47 \%,-4.9 \%$ and $-5.42 \%$ under B1 scenarios, and $-4.52 \%,-5.19 \%$ and $-6.47 \%$ under A2 scenarios, for the period of 2030s, 2050s and 2080s, respectively. This modeling result was confirmed with the temperature elasticity of streamflow (Figure 6c). The mean temperature elasticity of streamflow were $-3.88 \% /{ }^{\circ} \mathrm{C}$ (i.e., every $1{ }^{\circ} \mathrm{C}$ increase of mean temperature results in approximately $3.88 \%$ decrease of streamflow), $-2.73 \% /{ }^{\circ} \mathrm{C}$ and $-2.14 \% /{ }^{\circ} \mathrm{C}$ under $\mathrm{A} 1 \mathrm{~B}$ scenarios, and $-4.49 \% /{ }^{\circ} \mathrm{C},-3.3 \% /{ }^{\circ} \mathrm{C}$, and $-2.69 \% /{ }^{\circ} \mathrm{C}$ under B1 scenarios, and $-4.28 \% /{ }^{\circ} \mathrm{C},-2.9 \% /{ }^{\circ} \mathrm{C}$, and $-2.03 \% /{ }^{\circ} \mathrm{C}$ under A2 scenarios, for the 2030s, 2050s, to 2080s, respectively.

It can be seen that the temperature elasticity is not a constant, but decreases gradually as temperatures rise. It is because actual evaporation increases as temperatures rise under normal precipitation, but when the temperature rises to a certain extent, the actual evaporation will reach the maximum that equals the wet environmental evapotranspiration (Brutsaert, 1979; Fu et al., 2009b). The streamflow will not reduce at this stage, and the temperature elasticity will be a constant.

Compared with the other existing studies, the temperature elasticity of the Wujiang River watershed seems consistent with that of Sacramento basin of California (Risbey and Entekhabi, 1996), but was much less than those of the Spokane River watershed (Fu et al., 2007a), the Yellow River basin (Fu et al., 2007b) and the MurrayDarling basin (Yu et al., 2010). The reason needs further investigation, but may be due to the smaller size of watershed resulting in shorter convergence process of precipitation, ground-surface water interaction in the krast regions, land use/land cover, as well as precipitation characteristics.

\section{Impacts of precipitation change on streamflow}

The streamflow increases (decreases) with the increase (decrease) of precipitation under all emission scenarios and for all study periods (Figure 7b), i.e., streamflow will change (the air temperature keep the same means the air temperature change is 0,for example in Figure 8, in this condition we studied the streamflow change with the precipitation change) $0.96 \%, 4.36 \%$ and $8.36 \%$ under A1B scenarios as the precipitation increase $0.67 \%, 3.06 \%$ and $5.86 \%$ respectively; $0.79 \%, 1.97 \%$ and $4.56 \%$ under B1 scenarios as the precipitation increase $0.55 \%, 1.38 \%$ and $3.2 \%$ respectively; and $-1.28 \%, 0.78 \%$ and $5.28 \%$ under A2 scenarios with the precipitation change $-0.92 \%, 0.53 \%$ and $3.7 \%$, for 2030 s, 2050 s and 2080 s, respectively. The pattern of streamflow responses across scenarios, GCMs, and study periods, was almost identical to that of precipitation change when the air temperature keeps the same (Figure 7). This leads to a 

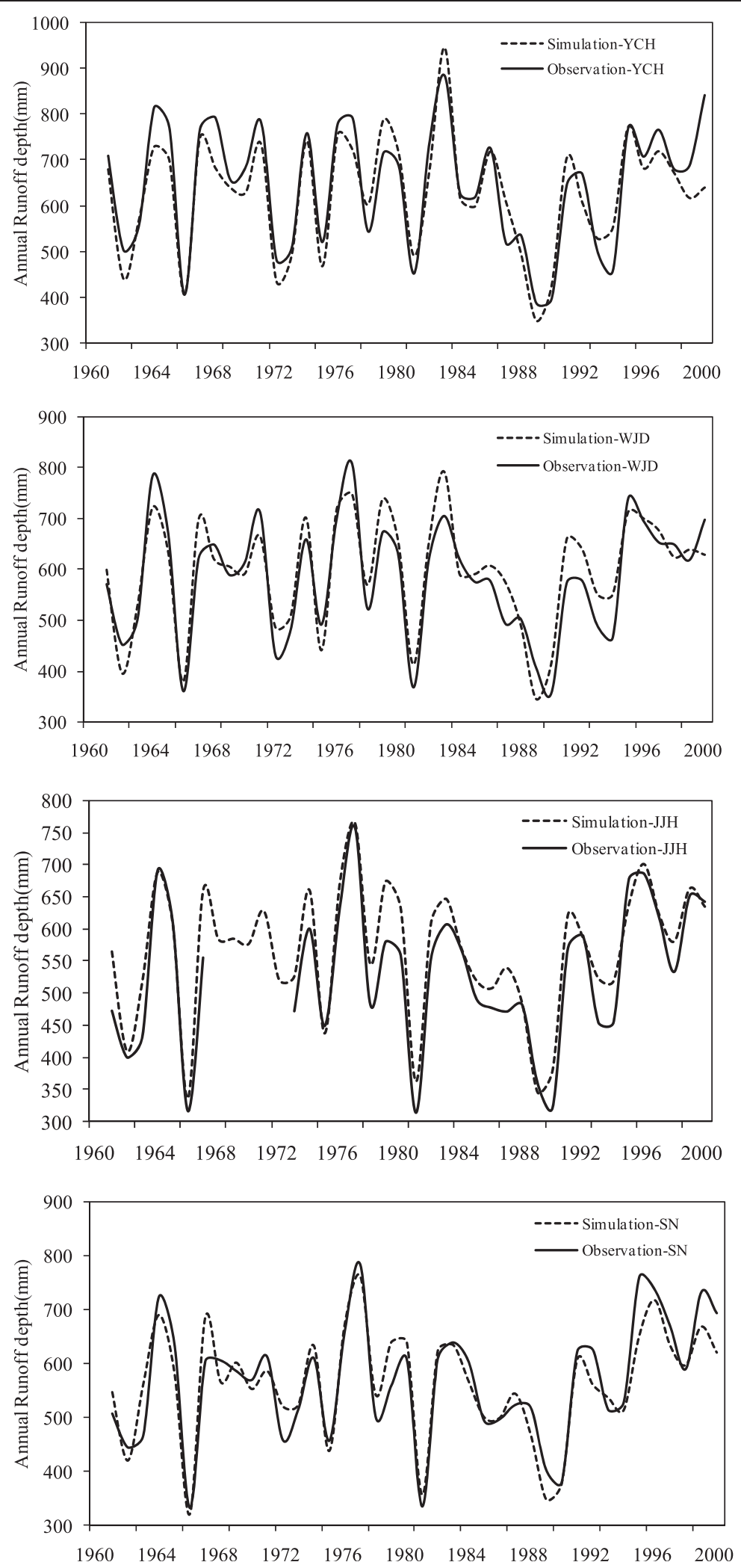

Figure 5 Observed and simulated monthly streamflow depth of the Wujiang River watershed at four sub-basin outlets during 1960-2000. 

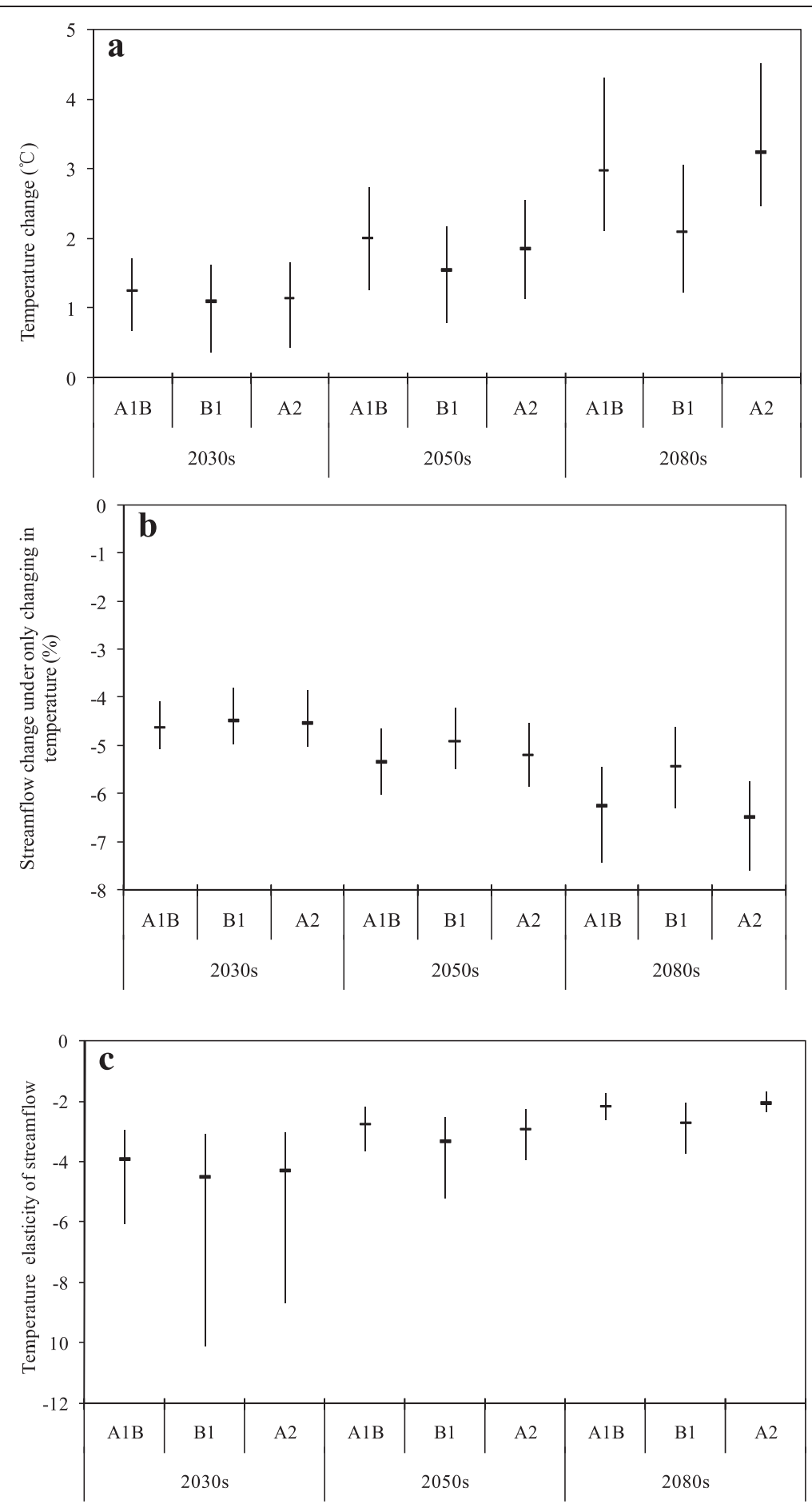

Figure 6 The future temperature change scenarios (a), streamflow responses (b), and the temperature elasticity of streamflow of the Wujiang River watershed (c) for the 2030s, 2050s and 2080s under IPCC A1B, B1 and A2 emission scenarios.

consistent of 1.42 of precipitation elasticity of streamflow for the Wujiang River watershed (Figure 7c). It is slightly smaller than that of the Spokane River watershed (1.67) (Fu et al., 2007a), the Yellow River basin
(1.69) (Fu et al., 2007b), the Murray-Darling basin (2.03.5) (Yu et al., 2010), and 1.5-2.5 of 1337 basins in the USA (Sankarasubramanian and Vogel, 2003). This may result from the facts that the Wujiang River watershed 

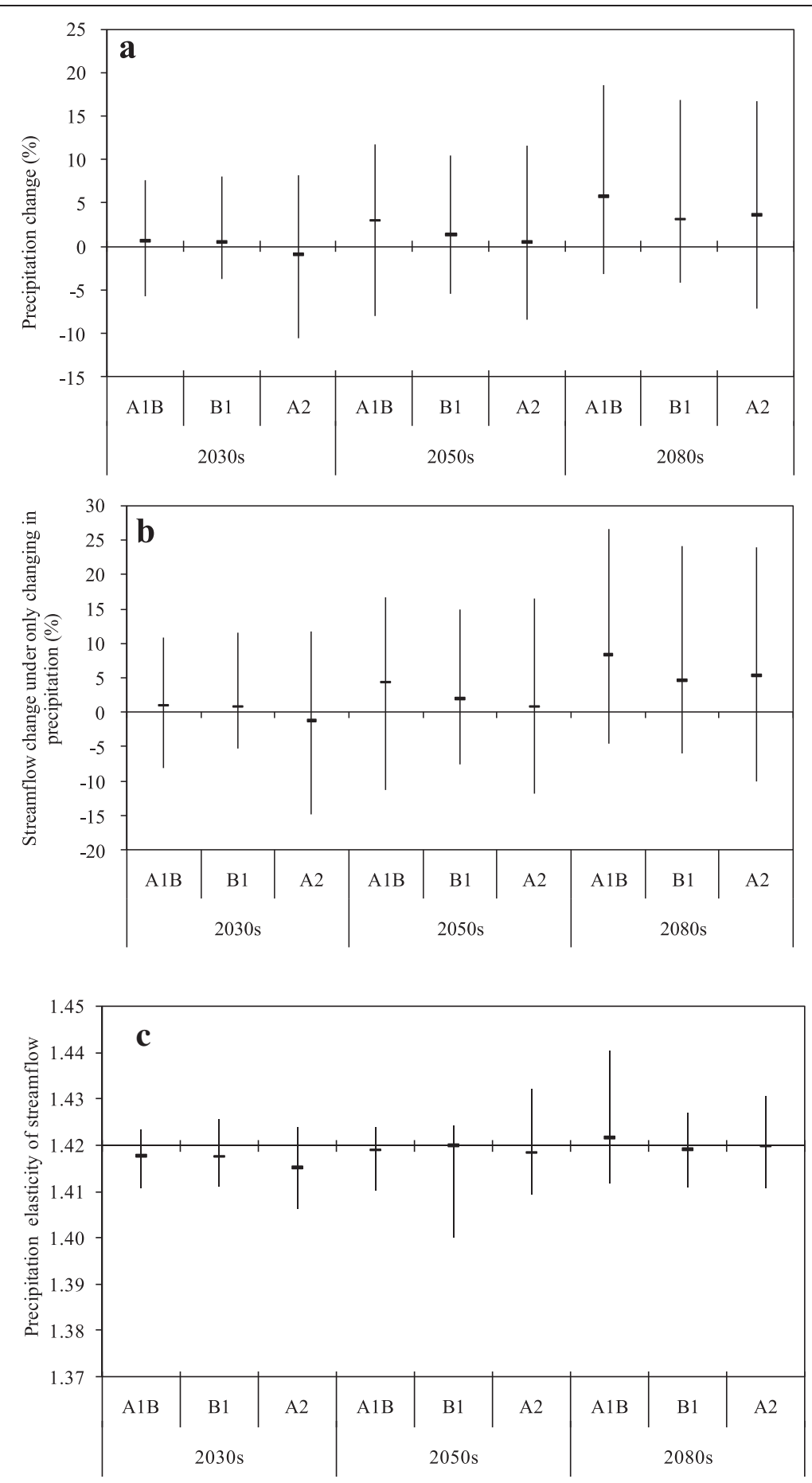

Figure 7 The future precipitation change scenarios (a), streamflow responses (b), and the precipitation elasticity of streamflow of the Wujiang River watershed (c) for the 2030s, 2050s and 2080s under IPCC A1B, B1 and A2 emission scenarios.

is located in humid karst region and is a typical mountain river. Its streamflow mainly comes from both precipitation and groundwater. The latter could contribute a large percentage of its streamflow in the Karst region, resulting in a smaller precipitation elasticity of streamflow in Karst regions than that in the non-Karst areas.
Impacts of both precipitation and temperature change on streamflow

Overall, a slight decrease of the future streamflow depth would be projected for the Wujiang watershed of the Guizhou Province, Southwest China, under different scenarios, though an increasing trend has been found under 


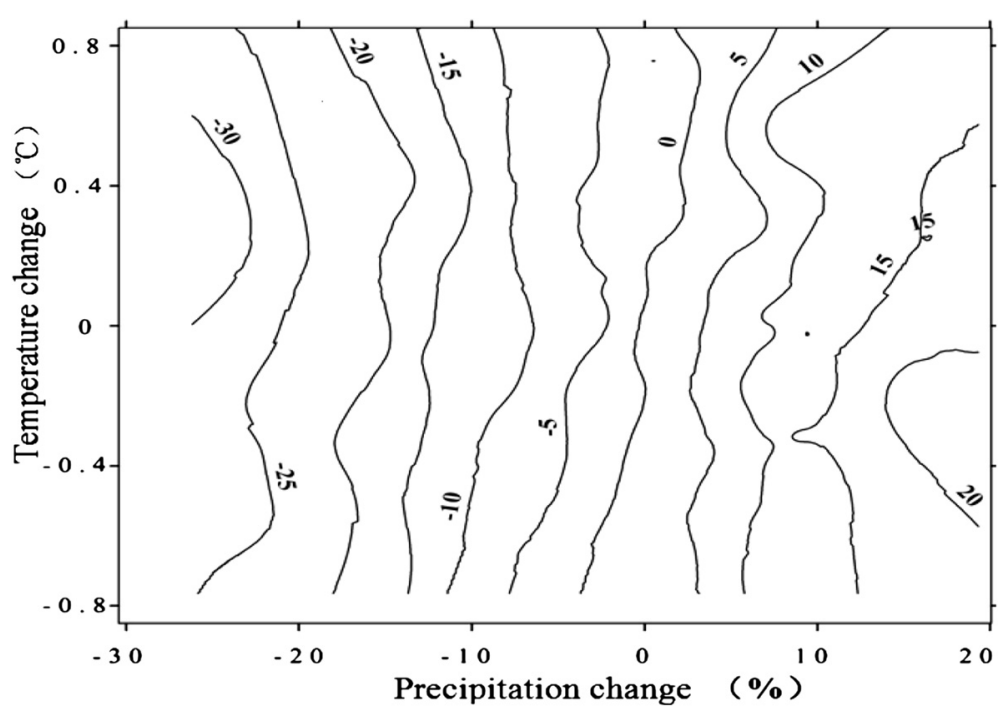

Figure 8 Contour plot of percentage annual streamflow anomaly as a function of annual percentage precipitation anomaly and absolute temperature change for the Wujiang River watershed from eleven interpolation techniques.

A1B scenarios for 2080 s period. Specially, the annual mean streamflow would change $-3.67 \%,-1.01 \%$ and $+2.04 \%$ under A1B scenarios, $-3.69 \%,-2.95 \%$ and $-0.9 \%$ under B1 scenarios, and $-5.79 \%,-4.41 \%$ and $-1.24 \%$ under A2 scenarios, for the 2030s, 2050s and 2080s, respectively. The overall streamflow responses to both precipitation and temperature were almost identical to that of streamflow responses to precipitation only (Figure 7 and Figure 9). It confirms the general rule that the precipitation is the dominate factor affecting runoff generation. However, the streamflow response magnitude and signs have been modified by the temperature, implying the effect of temperature on the streamflow cannot be neglected in spite of its independent slight effects. For example, the signs of future precipitation and streamflow are opposite, i.e., the slightly decline of streamflow in the future is associated with an increase of precipitation and a higher temperature. It indicates that the temperature is also critical for the regional runoff generation in the Wujiang River watershed, although much greater streamflow sensitivity to precipitation than temperature sensitivity to streamflow has been identified. This is understandable given precipitation is the controlling factor for runoff generation and higher temperatures are a second order effect usually leading to increased evaporation and transpiration (Yu et al., 2010).

\section{Comparisons with the observed streamflow in the last $\mathbf{5 0}$ years}

As shown in Figure 10, a slight increasing trend of the future streamflow with monthly and seasonal difference

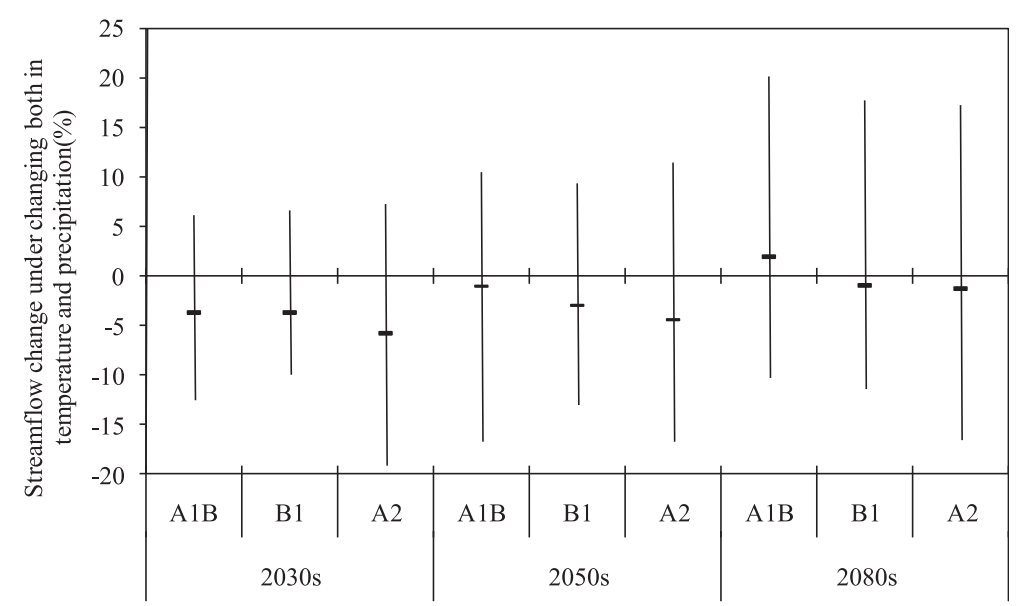

Figure 9 Streamflow response to both precipitation and temperature of the Wujiang River watershed for the 2030s, 2050s and 2080s under IPCC A1B, B1 and A2 emission scenarios. 


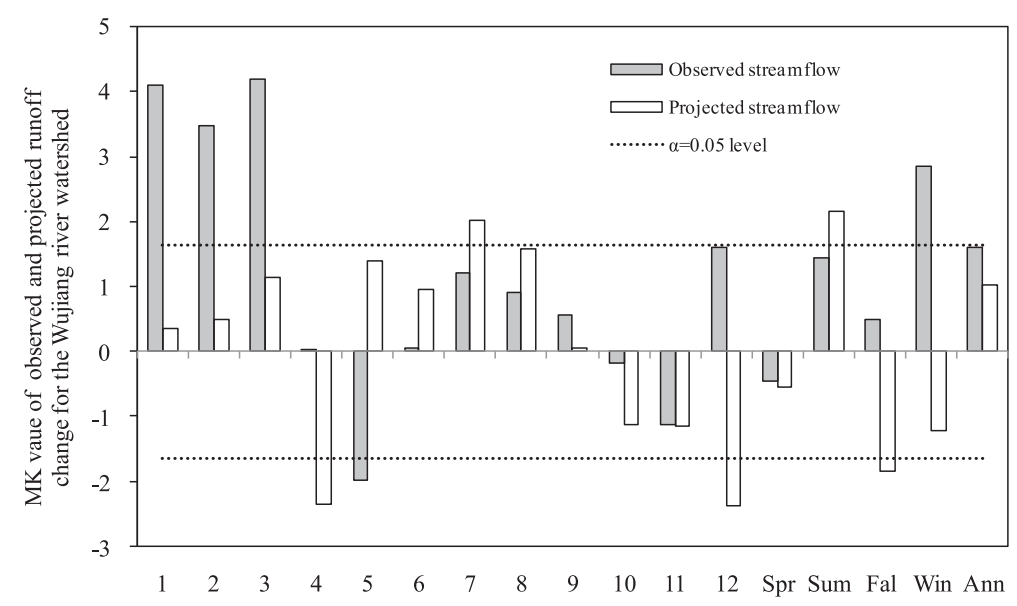

Figure 10 The MK testing statistic of future (2000-2100) and observed (1961-2000) monthly and seasonal streamflow of the Wujiang River watershed.

has been found for the Wujiang River watershed for both 1961-2000 observation and 2011-2100 projections. A notable feature of future streamflow change is a strong seasonality: a wetter summer and drier other seasons. The increasing trend in July is statistically significant at $\alpha=0.05$ level whereas the decreasing trends for both April and December also are statistically significant at $\alpha=0.05$ level. The trends of future streamflow for both summer and spring are consistent with those of the observations during the last 50 years, while the other two seasons have opposite signs with the observation (Figure 10). However, they are not consistent in term of monthly scale. For example, the decrease of future spring streamflow results mainly from that in April, while the observation indicated that spring streamflow mainly comes from that in May. The seasonal shifting of streamflow, to a certain degree, would increase the frequencies of extreme events: more summer flooding and spring drought. Summer is the flooding season for the study watershed, and an increase of summer streamflow in the future could potentially increase flood frequency. On the other hand, spring is the crop growing season needing irrigation, and a decline of streamflow in the future may possibly be detrimental to agriculture sector. This also would produce serious challenges for water resources management and likely lead to exacerbated problems for agriculture, industry, urban communities, and the environment (Qin et al., 2010b). For example, severe drought crippling southwest China between autumn 2009 and May 2010 were one of the worst in a century. According to Xinhua, the nation's state media (Hance, 2010), the severe drought has gravely affected agricultural production, nearly a million hectares could not produce crops, and caused price increases for rice, sugar, tea, etc., and left 16 million people without easy access to drinking water; over 50 million people are affected; while some rivers have dried up completely, and at the same time likely lead to exacerbated problems for environment (Qin et al., 2010b).

\section{Results of the two-parameter climate elasticity of streamflow approach}

Although the magnitudes and patterns of streamflow response to changes in precipitation and temperature differ due to varied interpolation algorithms, the streamflow is positively related to precipitation but slightly negatively related to temperature, with the precipitation-streamflow sensitivity greater than the streamflow-temperature sensitivity (Figure 8). This result is remarkably consistent with that of monthly water balance model as stated in the previous sections. It is also similar to the results of the Sacramento Basin (Risbey and Entekhabi, 1996). That is, the basin streamflow amount displays a strong dependence on precipitation, but virtually no dependence on temperature. However, it is distinctly different from the Murray-Darling Basin (Yu et al., 2010), the Yellow River Basin and the Spokane River Basin (Fu et al., 2007a, b), in terms of temperature impacts on streamflow. However, in term of precipitation elasticity of streamflow, these four watersheds seem to respond in a similar pattern with slightly difference of magnitudes.

A $20 \%$ precipitation increase in the Wujiang watershed results in a $22 \%$ increase in streamflow under normal temperature condition, but still $17 \%$ increase in streamflow under a temperature of $+0.8^{\circ} \mathrm{C}$ and $27 \%$ increase in streamflow under a temperature of $-0.5^{\circ} \mathrm{C}$ scenarios. A $20 \%$ precipitation decrease would results in $30 \%$ decrease in streamflow if the temperature was normal but $25 \%$ decrease in streamflow if the temperature was $0.4^{\circ} \mathrm{C}$ lower than normal.

Figure 11 indicates that the climate elasticity of streamflow changes with both precipitation and temperature and 


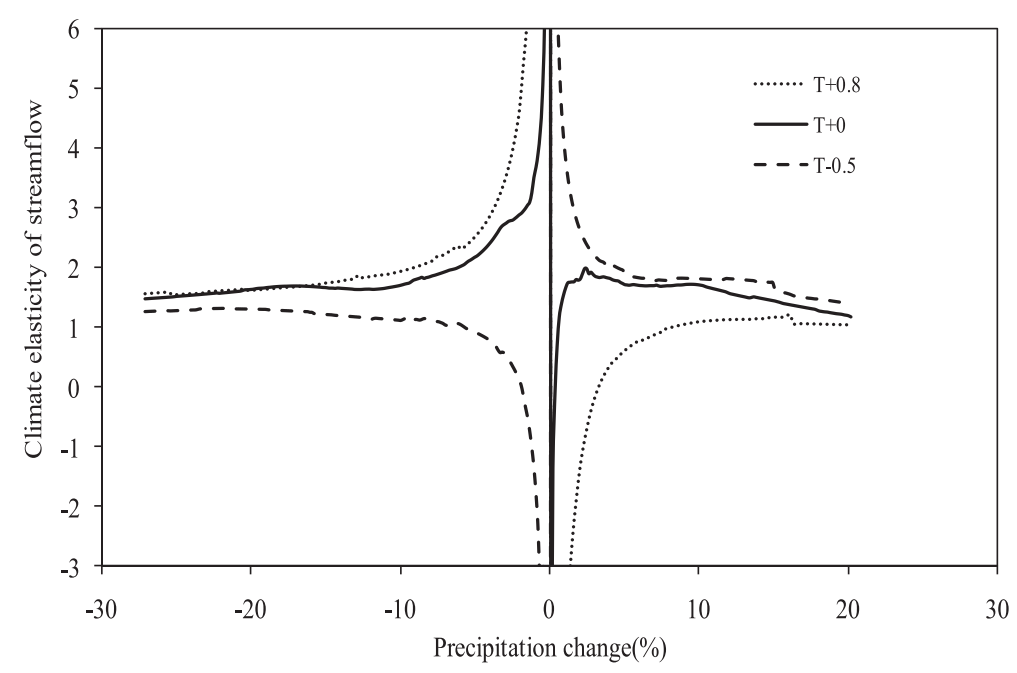

Figure 11 The climate elasticity of streamflow as a function of precipitation changes at different temperature scenario for the Wujiang River watershed.

mainly depends on precipitation. Excluding the non-stable values within $+10 \%$ precipitation changes, a $1 \%$ precipitation increase generally results in a $1.15-1.69 \%$ (mean $1.42 \%$ ) increase in streamflow and a $1 \%$ precipitation decrease generally results in $1.46-1.69 \%$ decrease in streamflow. Thus streamflow is relative more sensitive to decreasing precipitation (Figure 11). The analysis indicates that precipitation is a critical factor that controls regional runoff whereas the impact of temperature cannot be neglected. This conclusion is exactly the same as that of monthly water balance model in the previous sections, with slightly difference being described in the next section.

\section{Comparison of the simulations using hydrological model and climate elasticity approach}

This study used two different approaches to simulate the streamflow response to climate changes. Their results are almost identical in term of precipitation elasticity of streamflow. This is also consistent with results of $\mathrm{Ma}$ et al. (2010). The precipitation elasticity is almost a constant of 1.42 if the temperature holds the same, which implies that both methods can be used to investigate the effects of climate change on water availability and hydrological regimes in the study watershed. This also confirms the reasonable hydrological model parameters. As a result, one can select the two-parameter climate elasticity of streamflow approach due to its simplicity and less data requirements. Each of these two approaches has its respective advantages and disadvantages: the climate elasticity approach is based on a regression method to establish the streamflow-precipitation-temperature relationship to estimate the impact of climate variation on the water resources. The hydrological model, on the other hand, is based on a physical process of runoff generation to simulate the impact of climate change on the streamflow. Different principals but almost identical results have been achieved, which could strengthen our confidence on the reported results of impacts of climate change on water availability in this study.

However, the temperature elasticity of streamflow from the hydrological model is smaller than that of the climate elasticity approach. It may be due to the radiationbased evapotranspiration formula was applied to calculate potential evaporation in the hydrological model and we assumed future solar radiation keeps consistent, which may not be true in the future climate change scenarios. In addition, this radiation-based potential evapotranspiration formula may be less sensitive to temperature change.

\section{Uncertainties of results}

The dominant source of uncertainty of this study comes from regional climate change scenarios from different climate models, and uncertainties of hydrological model parameters seem playing secondary roles. This is because the climate change projections from GCMs have large uncertainties (Wilby et al. 2000), especially on regional scales (Trenberth, 1997; Giorgi and Francisco, 2000; Murphy et al., 2004; Fu et al. 2007b, 2009; Liu et al. 2009). As Figures 7 and 9 indicate, there is little difference between inter-scenario variability for both precipitation and temperature scenarios at any periods, compared with the huge differences across GCM models. For example, for A1B scenarios, the future temperature of different GCM models vary from 0.67$1.71^{\circ} \mathrm{C}$ for $2030 \mathrm{~s}$, to $1.26-2.74^{\circ} \mathrm{C}$ for $2050 \mathrm{~s}$, and even to $2.11-4.3^{\circ} \mathrm{C}$ for $2080 \mathrm{~s}$, respectively. The difference among different climate models also increase with time. 
Compared with the temperature differences resulting from different GCM models, much greater divergence exists for precipitation due to opposite signs of future precipitation projections from varied GCM models. For example, for $\mathrm{A} 1 \mathrm{~B}$ scenarios, the maximum precipitation difference among GCM models reaches 13.23\% (-5.66$7.57 \%)$ for $2030 \mathrm{~s}, 19.72 \%(-8.01-11.71 \%)$ for $2050 \mathrm{~s}$, and $21.76 \%(-3.19-18.57 \%)$ for 2080 s, respectively. As similar to temperature projections, the differences increase with time.

However, the importance of different scenarios might be critical for future 50-100 year projections. For example, the magnitudes of annual temperature change are very close $\left(0.05-0.15^{\circ} \mathrm{C}\right)$ for 2030 s from three different emission scenarios but it could be as large as $1.15^{\circ} \mathrm{C}$ between B1 and A2 scenarios for 2080s.

The critical concern is that the observed precipitation trends over the last 40 years in the study watershed showed a rise in total annual precipitation whereas the future climate change predictions of some models project a decrease in precipitation. This casts doubts on the validity of the GCM results. It implies that a single GCM output may give a totally incorrect sign of future precipitation. For example, the magnitude of observed precipitation trend was about $1.16 \mathrm{~mm} / 10$ years in the Wujiang River watershed, but the projected precipitation trend from BCCR-BCM20, CNRM-CM3, CSIRO-MK30, GFDL-CM21, and INM-CM30 would project a decrease of precipitation for 2030s under A1B scenarios. It justifies the conclusion that multi-GCMs models should be used be for any climate change impact studies (Fu et al., 2009). In the next steps, the authors will further examine the accuracy of each GCM 20th century run (IPCC 20C3M) against the observations during 1961-2000 for the study watershed to better quantify the link between projected climate change and water availability in the Wujiang River catchment.

Uncertainty in hydrological modeling also exists, although it is generally smaller than future climate change projections (Bates et al., 2008). Although most hydrological models calibrate and simulate streamflow well with historical data under the current climate, these calibrated parameters may not be suitable for future climate scenarios. For example, Nash and Gleick (1991) and Schaake (1990) used the National Weather Service River Forecasting System (NWSRFS) to perform climate sensitivity analyses on the Animas River at Durango, Colorado. When precipitation was increased by $10 \%$, holding temperature and potential evapotranspiration constant, Nash and Gleick (1991) and Schaake (1990) reported an 11\% and 20\% increase, respectively, in annual streamflow. This is a rather remarkable difference, considering the same model was applied to the same basin in both instances. In addition, potential evapotranspoartion is required to drive any hydrological model and accurate estimation of it still a challenging issue. The Priestley-Taylor formula was used in this study, and its uncertainty in the future climate change scenarios is not explored in this study.

Our analysis uses historical observed data for the last 40-60 years assuming that the streamflow precipitationtemperature relationship is independent of land surface change, such as land use/land cover change, which could change the characteristics of the hydrological cycle, including infiltration, evapotranspiration, and runoff generation processes. When used to assess the effect of projected future climate on streamflow, it again assumes that the current rainfall-runoff relationship is still valid under the future climate change scenarios (Fu et al. 2007b).

\section{Conclusions}

Southwest China has relatively abundant rainfall, but experiences a quite number of droughts and flooding in the last 40-50 years due to the uneven distribution of rainfall in both space and time, as well as the most complex topography in the world. This leads to serious water shortage, deterioration of ecological environment and karst rocky desertification.

Based on IPCC AR4 GCM future climate projection scenarios, the hydrological modeling simulation results indicate that the annual mean streamflow would change $-3.67 \%,-1.01 \%$ and $+2.04 \%$ under A1B scenarios, $-3.69 \%,-2.95 \%$ and $-0.9 \%$ under B1 scenarios, and $-5.79 \%,-4.41 \%$ and $-1.24 \%$ under A2 scenarios, for 2030s, 2050s and 2080s respectively, while compared with the base period (1961-2000) for the Wujiang River watershed. The streamflow response showed almost the same pattern as that of precipitation across emission scenarios and climate models, confirming that the precipitation is the primary factor affecting runoff generation. However, the effects of temperature on the streamflow cannot be neglected with evidences of opposite signs of future precipitation and streamflow; the slightly decline of streamflow is associated with an increase of precipitation and a higher temperature.

While the magnitudes of annual mean streamflow responses are minor, there would be a seasonal shift: drier spring and wetter summer. This seasonality, being consistent with the observed hydro-climate trend in the last 40-50 years (Qin et al., 2010b), would potentially result in more frequencies of spring drought events and summer flooding. This could bring serious challenge for water resources planning and management in the Southwest China, as the severe drought crippling southwest China between autumn 2009 and May 2010 followed by a serious flooding and associated landslides in June and July 2010.

Two different approaches obtained almost identical results in term of precipitation elasticity of streamflow, 
which is about 1.42 across different emission scenarios, GCMs, as well as study periods. However, the temperature elasticity of streamflow was relatively smaller than that the empirical climate elasticity approach. This may be due to the facts that radiation-based evapotranspiration formula was applied to calculate potential evaporation in the hydrological model and we assumed future solar radiation keeps consistent, which may not be valid in the climate change scenarios. In addition, this radiation-based potential evapotranspiration formula may be less sensitive to temperature change.

The dominant source of uncertainty of this study comes from regional climate change scenarios from different climate models, and uncertainties of hydrological model parameters seem playing secondary roles. For example, different GCMs projected different signs of future precipitation changes, implying that current GCMs have very low confidence in projections for precipitation, especially at regional or basin scales. It indicates that a single GCM output may give a totally incorrect sign of future precipitation and confirms the existing the conclusion that multi-GCMs models should be used for any climate change impact studies. The uncertainty in future projected precipitation changes produces uncertainty in future streamflow for the studied basins. Therefore, one future research priority will be to assess the accuracy of each GCM 20 century run (IPCC 20C3M) against observations during 1961-2000.

Although there are some uncertainties regarding the results of this study, it still helps us to improve our understanding of hydrological consequences of climate changes, especially in the karst region of Southwest China. It also could be served as a reference for regional water resource planning and management and restoration and reconstruction of karst eco-environment area, and possibly a basis for better understanding the hydrological processes and sustainable development of karst area under climate change scenarios.

\section{Competing interests}

The authors declare that we have no competing interests.

\section{Authors' contributions}

The work presented here was carried out in collaboration between all authors. $\mathrm{NQ}, \mathrm{HL}$ and $\mathrm{XC}$ defined the research theme. NQ, JW and $\mathrm{HL}$ designed methods and experiments, performed the statistical analysis, analyzed the data, interpreted the results and wrote the paper. XC and GY co-worked on conceived of the study, and participated in its design and coordination and helped to draft the manuscript, associated data collection and their interpretation. XC and JW co-designed experiments, discussed analyses, interpretation, and presentation. All authors have contributed to, read and approved the final manuscript.

\section{Acknowledgements}

This paper is financially supported by a National Natural Science Foundation of China (Formation Mechanism and counter measures of extreme drought events in Southwest China under changing environments, Grant No. 41461007) and National Basic Research Program ("973Program", 2012CB417000), and Guangxi science and Technology Department Program (Grant No. 2014DD29090).
We would like to thank the National Climate Centre in Beijing, China, for providing valuable climate data.

\section{Author details}

${ }^{1}$ Laboratory of Beibu Gulf Environment Change and Resources Use, Ministry of Education, Guangxi Teachers Education University, Nanning 530001, China. ${ }^{2}$ State Key Laboratory of Hydrology-Water Resources and Hydraulic Engineering, Hohai University, Nanjing 210098, China. ${ }^{3}$ State Key Laboratory of Lake Science and Environment, Nanjing Institute of Geography and Limnology, CAS, Nanjing 210008, China. ${ }^{4}$ The Collaborative Innovation Center of the Ecological Environment \& Integration Development in the Xijiang River Basin, Xijiang River, China.

Received: 13 August 2014 Accepted: 17 January 2015

Published online: 02 April 2015

\section{References}

Arnell N (2002) Hydrology and global environmental change. Prentice Hall, Englewood Cliffs, N.J

Bates BC, Kundzewicz ZW, Wu S, Palutikof JP (eds) (2008) Climate Change and Water. Technical Paper of the Intergovernmental Panel on Climate Change. IPCC Secretariat, Geneva, p 210

Brutsaert W (1979) Stricker H An advection-aridity approach to estimate actual regional evapotranspiration. Water Resource Research 15:443-449

Butscher C, Huggenberge P (2009) Modeling the Temporal Variability of Karst Groundwater Vulnerability, with Implications for Climate Change. Environ Sci Technol 43:1665-1669

Chen X, Chen Y, Xu C (2007) A distributed monthly hydrological model for integrating spatial variations of basin topography and rainfall. Hydrolog Process 21:242-252

Chen X, Fang C, Zhang Y (2012) Review on the Impact of Climate Change on Features of Hydrology and Water Resources. Clim Change Res Lett 1:96-105

China's National Climate Change Program (2007) National Development and Reform Commission People's Republic of China, p 1-62

Fan G, Lv S, Cheng G (2003) Simulation of influence of climate change on wate resource over luanhe river valley using a hydrological model(II): Simulated results analysis. Climatic and environment research 8(1):302-310

Ford DC, Williams PW (1989) Karst geomorphology and hydrology. Unwin Hyman, London

Fu GB, Chen S, Liu C, Shepard D (2004) Hydro-climatic trends of the Yellow River basin for the last 50 years. Clim Change 65:149-178

Fu GB, Barber ME, Chen S (2007a) Impacts of climate change on regional hydrological regimes in the Spokane River watershed. J Hydrolog Eng 12:452-461

Fu GB, Charles SP, Chiew FH (2007b) A two-parameter climate elasticity of streamflow index to assess climate change effects on annual streamflow. Water Resour Res 43:W1 1419, doi:10.1029/2007WR005890

Fu B, Wand Y, Ren Y, Liu C, Xu P (2008) Study on rain-runoff process in the peripheral mountainous area of the Sichuan Basin. Chin J Geochem 27:183-188

Fu GB, Charles SP, Yu JJ, Liu CM (2009) Decadal climatic variability, trends and future scenarios for the North China Plain. J Climate 22:2111-2123

Giorgi F, Francisco R (2000) Evaluating uncertainties in the prediction of regional climate change. Geophys Res Lett 27:1295-1298

Gleick PH (1990) Vulnerability of water systems. In: Waggoner PE (ed) Climate Change and U.S. Water Resources. Wiley, New York

Guo SL, Wang JX, Xiang LH, Wing AW, Li DF (2002) A macro-scale and semidistributed monthly water balance model to predict climate change impacts in China. J Hydrol 268:1-15

Han Z, Jin ZS (1996) Hydrology of Guizhou Province. Seismology Press, Beijing, p 508

Han G, Liu C (2001) Hydrogeochemistry of Wujiang River water in Guizhou Province, China. Chin J Geochem 3:240-248

Hance M (2010) Drought crippling southwest China, millions without drinking water [Available online at http://news.mongabay.com/2010/0321 hance china drought.html]. http://ipcc-ddc.cru.uea.ac.uk

Hao Z, Wang J, Li L, Wang Z, Wang L (2006) Impact of Climate change on runoff in the Riverhead of Yellow River. Journal of Glaciology and Geocryology 28(1):1-7

Huang J (2007) Guizhou: the situation of water shortage is grim, over 50\% cities and towns face a shortage of water [Available online at http://sei.gov.cn/ showArticle.asp?ArticlelD=105021] 
Information center of the Ministry of Water Resources of China (2000) The performance criteria according to the standards for hydrological information and forecasting.

Jiang H, Feng X, Dai Q (2005) Damming effect on the distribution of mercury in Wujiang river. Chin J Geochem 24:179-183

Jin X, Huang Y, Yang W, Chen L (2009) Analysis of impact of future climate change on water resources in Yangtze River Basin. Yangtze River 40(8):35-38

Lettenmaier DP (1991) Climate sensitivity of California water re-sources. J Water Resour Plann Manag 117(1):108-125

Liu J, Chen X, Zhang J, Flury M (2009) Coupling the Xinanjiang model to a kinematic flow model based on digital drainage networks for flood forecasting. Hydrolog Process 9:1337-1348

Ma H, Yang D, Tan SK, Gao B, Hu Q (2010) Impact of climate variability and human activity on stream-flow decrease in the Miyun Reservoir catchment. J Hydrolog 389:317-324

McCarthy JJ, Canziani OF, Leary NA, Dokken DJ, White KS (2001) Climate change 2001: Working Group II: Impacts, Adaptation and Vulnerability, Contribution of Working Group II to the Third Assessment Report of the Intergovernmental Panel on Climate Change. Cambridge University Press, Cambridge, U.K

Murphy JM, Sexton DMH, Barnett DN, Jones GS, Webb MJ, Collins M, Stainforth DA (2004) Quantification of modelling uncertainties in a large ensemble of climate change simulations. Nature 430:768-772

Nash LL, Gleick PH (1991) Sensitivity of streamflow in the Colorado basin to climatic changes. J Hydrol 125:221-241

Nash J, Sutcliffe J (1970) River flow forecasting through conceptual models part I- A discussion of principles. J Hydrol 10:282-290

Phillips TJ, Gleckler PJ (2006) Evaluation of continental precipitation in 20th century climate simulations: The utility of multimodel statistics. Water Resources Research 42, doi:10.1029/2005WR004313.

Priestley CHB, Taylor RJ (1972) On the assessment of the surface heat flux and evaporation using large-scale parameters[J]. Monthly Weather Review 100:81-92

Qin N, Chen X, Fu GB, Zhai J, Xue X (2010a) Precipitation and temperature trends for the Southwest China: 1960-2007. Hydrological processes 24, doi:10.1002/hyp.7792

Qin N, Chen X, Xue X, Ling M, Zhang Z (2010b) An applicability study of potential evapotranspiration models in Guizhou Province. Advances in Water Science 21:357-363 (in Chinese)

Risbey JS, Entekhabi D (1996) Observed Sacramento Basin streamflow response to precipitation and tempera ture changes and its relevance to climate impacts studies. J Hydrol 184:209-223

Sankarasubramanian A, Vogel RM (2003) Hydroclimatology of the continental United States. Geophys Res Lett 30(7):1363, doi:10.1029/2002GL015937

Sankarasubramanian A, Vogel RM, Limbrunner JF (2001) Climate elasticity of streamflow in the United States. Water Resour Res 37(6):1771-1781

Schaake JC (1990) From climate to flow. In: Wag-goner PE (ed) Climate Change and U.S. Water Resources, vol 8. John Wiley, New York, pp 177-206

Smith K, Richman MB (1993) Recent hydroclimatic fluctuations and their effects on water resources in Illinois. Clim Change 24(2):249-269

Song L, Zhang Y, Fang J, Gu Z (1983) Karst development and the distribution of karst drainage systems in Dejiang, Guizhou Province, China. J Hydrol 61:3-17

Tang C, Liu C (2007) Simulation of surface runoff in theWujiang River watershed based on GIS. Chin J Geochem 6:284-289

Trenberth KE (1997) The use and abuse of climate models [J]. Nature 386:131-133

Wang G (2006) Research on key issues of climate change impacts on hydrology and water resources in the middle reaches of the Yellow River [D]. HoHai University.

Wang S, Li R, Sun C, Zhang D, Li F, Zhou D, Xiong K, Zhou Z (2004a) How types of carbonate Rock Assemblages constrain the distribution of Karst Rocky Desertified land in Guizhou Province, PR China: Phenomena and Mechanisms. Land Degrad Dev 15:123-131

Wang S, Liu Q, Zhang D (2004b) Karst Rocky Desertification in southwestern China: Geomorphology, landuse, impact and rehabilitation. Land Degrad Dev 15:115-121

Wilby RL, Hay LE, Gutowski WJ Jr, Arritt RW, Takle ES, Pan Z, Leavesley GH, Clark MP (2000) Hydrological responses to dynamically and statistically dowNSEaled climate modeloutput. Geophys Res Lett 27:1199-1202

Wurbs RA, Muttiah RS, Felden F (2005) Incorporation of climate change in water availability modeling. J Hydrolog Eng 10:375-385

Xiong LH, Guo SL (1999) A two-parameter monthly water balance model and its application. J Hydrol 216:111-123
Xue X (2010) Study of Karstic Watershed Hydrological Model and Parameters Regionalisation in Southwest China. Hohai University, Dissertation of PHD Yang H (1988) The fragile karst environment. In: Guizhou Society of Environmental Science: A Study on the Karst Environment in Guizhou, vol. 17. Guizhou People's publishing Press

Yang T, Chen X, Xu C, Zhang Z (2009) Spatio-temporal changes of hydrological processes and underlying driving forces in Guizhou region, Southwest China. Stoch Environ Res Risk Assess 23:1071-1087

Yates DN, Strzepek KM (1998) Modeling the Nile basin under climatic change. J Hydrol Eng 3(2):98-108

Yu J, Fu GB, Cai W, Cowan T (2010) Impacts of precipitation and temperature changes on annual stream-flow in the Murray-Darling Basin. Water Int 35:313-323

Yuan D (1997) Rock desertification in the subtropical karst of south China. Zeitschrift fur Geomorphologie NF 108:81-90

Yuan F, Xie Z, Ren L, Huang Q (2005) Hydrological variation in Haihe River Basin due to climate change. J Hydraul Eng 36(3):274-279

Yuan ZJ, Shen YJ, Chu YM, Qi YQ (2009) Variations and Distribution of Temperature and Precipitation of Haihe River Basin in Recent 40 Years[J]. Research of Soil and Water Conservation 16(3):24-26

Zhang J, Wang G (2007) Research on the impact of climate change on hydrology and water resources. Science press, Beijing, pp 32-49

Zhang GS, Li L, Shi XH, Xu WX, Dong LX, Wang QC (2000) Climatic changes over the upper yellow river land its affection on water resources. Advance in water resources 11(3):277-283

Zhu J, Wand Y, Liu C, Tao F (2005) A preliminary study on the distribution characteristics of nutrients (N, P, Si, C) in the Wujiang River Basin. Chin J Geochem 24:352-360

\section{Submit your manuscript to a SpringerOpen ${ }^{\circ}$ journal and benefit from:}

- Convenient online submission

- Rigorous peer review

- Immediate publication on acceptance

- Open access: articles freely available online

- High visibility within the field

- Retaining the copyright to your article

Submit your next manuscript at $>$ springeropen.com 